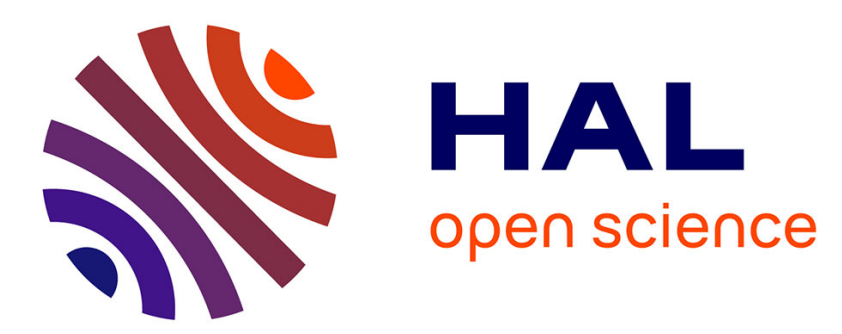

\title{
Assessment of a blood preservation protocol for use in ferrets before transfusion.
}

Charly Pignon, T M Donnelly, C Todeschini, Jack-Yves Deschamps, F A Roux

\section{To cite this version:}

Charly Pignon, T M Donnelly, C Todeschini, Jack-Yves Deschamps, F A Roux. Assessment of a blood preservation protocol for use in ferrets before transfusion.. The Veterinary record, 2014, 174 (11), pp.277. 10.1136/vr.102127 . hal-01164419

\section{HAL Id: hal-01164419 https://hal.science/hal-01164419}

Submitted on 16 Jun 2015

HAL is a multi-disciplinary open access archive for the deposit and dissemination of scientific research documents, whether they are published or not. The documents may come from teaching and research institutions in France or abroad, or from public or private research centers.
L'archive ouverte pluridisciplinaire HAL, est destinée au dépôt et à la diffusion de documents scientifiques de niveau recherche, publiés ou non, émanant des établissements d'enseignement et de recherche français ou étrangers, des laboratoires publics ou privés. 


\title{
Paper
}

\section{Assessment of a blood preservation protocol for use in ferrets before transfusion}

\author{
C. Pignon, T. M. Donnelly, C. Todeschini, J. Y. Deschamps, F. A. Roux
}

\begin{abstract}
Blood transfusion has been described in ferrets as a treatment for oestrus-associated anaemia and as a life-saving therapy following trauma, iatrogenic (usually surgery-induced) anaemia, autoimmune haemolytic anaemia and pure red cell aplasia. Although blood banking is a common method for storage of feline and canine blood it is not currently done with ferret blood. The aim of this study was to determine the shelf-life of ferret blood using the anticoagulant citrate-phosphate-dextrose-solution with adenine (CPDA). Two male ferrets were used as blood donors. From each ferret, $6 \mathrm{ml}$ of blood was taken from the cranial vena cava and stored in $10 \mathrm{ml}$ polyethylene terephthalate (PET) blood tubes containing $1 \mathrm{ml}$ of CPDA solution. Blood was taken from each ferret once per month for five months. These 10 blood samples were stored in a laboratory refrigerator at $4^{\circ} \mathrm{C}$ for four weeks. Biochemical (glucose, pH, lactate, potassium, sodium) and haematological (haematocrit, light microscopic blood smear examination) analyses were performed on the stored blood at days 0, 7, 14, 21 and 28. Biochemical analyses revealed a progressive decrease from day seven in the stored blood pH, glucose and sodium, with a concomitant increase in lactate and potassium. These results are attributable to the ongoing metabolism and deterioration of the red blood cells (RBC) while in storage, and are more rapid than described for human or canine stored blood. Haematological analyses revealed a progressive elevation of the haematocrit due to the appearance of hypochromic red blood cells and echinocytes beginning at day 7. Haemolysis was observed in the microhaematocrit capillary tube sample by day 21 , and microscopic clots were visible on the blood smear by day 28 . The low blood pH and the appearance of many hypochromic RBCs and some echinocytes from day 7 in CPDA-stored ferret blood, suggest stored ferret blood has a short shelf-life when compared with stored human or canine blood. We recommend that ferret blood stored in CPDA should not be used for transfusion after seven days of storage at $4^{\circ} \mathrm{C}$.
\end{abstract}

\begin{abstract}
Introduction
Blood transfusion in ferrets (Mustela putorius furo) has been described as a life-saving therapy following trauma, iatrogenic (usually surgeryinduced) anaemia, autoimmune haemolytic anaemia and pure red cell aplasia (Dutton 1999, Pollock 2007) and as a treatment for oestrusassociated anaemia (Ryland 1982). Administration of fresh donor blood within four hours of collection to the recipient (Hoefer 1992, Hillyer 1995, Lichtenberger 2004) seems to pose little clinical risk in ferrets (Hohenhaus 2004, Lichtenberger 2004), even without crossmatching as blood-groups of the kind found in other mammals do
\end{abstract}

Veterinary Record (2014)

\section{Pignon, DVM,}

T. M. Donnelly, BVSc, Dip ACLAM, Dip ABVP (Exotic Companion Mammal),

C. Todeschini, DVM,

Exotic Animal Medicine Service,

Alfort School of Veterinary Medicine, 7

Avenue du Général de Gaulle,

Maisons-Alfort 94700,

France

F. A. Roux, DVM, PhD, Dip ACVECC,

J. Y. Deschamps, DVM, PhD,

Emergency and Critical Care Unit, doi: 10.1136/vr.102127

LUNAM University, ONIRIS, The Nantes-Atlantic National College of Veterinary Medicine, Food Science and Engineering - La Chantrerie, CS 40706, Nantes 44 307, Cedex 03, France

E-mail for correspondence: cppignon@vet-alfort.fr

Provenance: not commissioned; externally peer reviewed

Accepted January 8, 2014 not appear to exist on ferret red blood cells (RBC) (Manning and Bell 1990). Although blood banking is a common method for storage of canine and feline blood (Feldman and Kristensen 1995), it is not currently practised with ferret blood.

Citrate-phosphate-dextrose-solution with adenine (CPDA) is a commercially available anticoagulant in which the added dextrose, phosphate and adenine favour the viability of RBCs, permitting the storage of human blood for five weeks and canine blood for three weeks (Wardrop and others 1997). CPDA has been recommended for ferret blood transfusion in a ratio of 1:9 (Morrisey 2010) and been used for immediate blood transfusion (11 $\mathrm{ml}$ whole blood: $2 \mathrm{ml}$ CPDA) in a multisystemic traumatised ferret (Kaelble 2000). Dutton (1999) described ferret blood stored in CPDA for 30 days transfused to a recipient ferret without clinically adverse effects. While transfusion of CPDA-stored ferret blood seems to be effective and safe, to the authors' knowledge, no data are available regarding the shelf-life of stored ferret blood. The objective of this preliminary in vitro study was to determine the effects of storing ferret blood in CPDA at $4^{\circ} \mathrm{C}$ for four weeks. Ideally, a recommendation of shelf-life (defined as the number of days after collection at which 75 per cent $\mathrm{RBC}$ viability is maintained) can be made based on in vitro observations.

\section{Materials and methods}

The study was conducted with the approval of the Research Ethics Committee of the Alfort School of Veterinary Medicine. Two 
young-adult male ferrets were selected as blood donors. Both ferrets were implanted with deslorelin-acetate (Suprelorin, Virbac, Carros, France) a gonadotrophin-releasing hormone agonist that suppresses testosterone (hormonal castration). The ferrets were healthy, vaccinated against canine distemper and rabies, negative on serology for Aleutian disease virus, negative for enteric parasites on faecal examination and had no previous medical problems. A blood biochemistry panel and complete blood count were performed at the start of the study and all measurements were within reference intervals. Before each blood collection, a complete physical examination, haematocrit and blood smear examination were performed. During the study, no physical examination abnormalities were detected, the haematocrit was always $>40$ per cent and no RBC morphological abnormalities were seen microscopically.

For blood storage, sterile collection tubes were prepared under a laminar airflow cabinet. From a $250 \mathrm{ml}$ small animal blood collection bag with CPDA (Animal Blood Resources International, USA), $1 \mathrm{ml}$ of CPDA was taken and placed into a $10 \mathrm{ml}$ sterile polyethylene terephthalate (PET) vacuum blood plain tube (Becton Dickson Company, UK). $6 \mathrm{ml}$ of blood was collected five times from each donor ferret, resulting in 10 samples, with a one-month interval between each collection. Blood was taken aseptically from the cranial vena cava under anaesthesia (sevoflurane 2.5 per cent and oxygen $0.8 \mathrm{l} / \mathrm{min}$ ). A 23G blood collection set (Becton Dickinson Company, UK) was connected to the PET blood storage tube so that the blood collection took place in a closed system. If the vacuum within the PET blood storage tube was insufficient for collecting blood, additional vacuum was provided by a 25G winged infusion set (Laboratoires Euromedis, France) attached to a $10 \mathrm{ml}$ syringe which was connected to the blood collection set by a three-way stopcock. The $6 \mathrm{ml}$ of blood from each donor ferret was collected directly into the PET vacuum blood tube containing CPDA in a ratio of $6 \mathrm{ml}$ of blood: $1 \mathrm{ml}$ CPDA. The blood was then immediately stored in a laboratory refrigerator at $4^{\circ} \mathrm{C}$ for four weeks.

In order to assess RBC viability, various tests were performed on the stored blood every seven days from the day of sampling (day 0) until day 28. Blood glucose (Accu-Chek Active Glucometer, Roche, USA), pH, electrolytes (Vetstat Electrolyte and Blood Gas Analyser, Idexx Laboratories, USA) and lactate (VetTest Chemistry Analyser, Idexx Laboratories, USA) were measured to evaluate the metabolism of the stored RBCs. To assess the morphology and number of whole RBCs, a capillary microhaematocrit and a blood smear examination (May-Grünwald-Giemsa stain) under a light microscope were performed.

A repeated-measures analysis of variance was performed on the biochemical and haematological measurements using a covariance pattern model including only one fixed factor (ie, age of blood sample - day 0, 7, 14 ...). Different covariance patterns (compound symmetry, autoregressive, Toeplitz and unstructured) were evaluated to take into account the correlation of measures within each blood sample and compared using the Akaike information criterion (AIC). All pairwise differences between age of blood samples were estimated and tested without adjustment for multiple comparisons. The analyses were performed using SAS/STAT(R) V.9.3 software, PROC MIXED programme (SAS Institute, Cary, North Carolina, USA).

\section{Results}

The glucose concentration of the stored blood was $643 \pm 67 \mathrm{mg} / \mathrm{dl}$ at day 0 and gradually decreased to $423 \pm 99 \mathrm{mg} / \mathrm{dl}$ by day 28 (Fig 1). Values for stored blood lactate increased rapidly from $1.96 \pm 0.82 \mathrm{mmol} / \mathrm{l}$ on day 0 to $15.27 \pm 2.29 \mathrm{mmol} / \mathrm{l}$ on day 28 (Fig 1), while stored blood $\mathrm{pH}$ decreased quickly from $6.99 \pm 0.70$ on day 0 to $6.66 \pm 0.03$ by day 7 , and below 6.60 by day 14, which was the minimal value detected by the analyser (Fig 1). Stored blood potassium increased progressively from $3.49 \pm 0.19 \mathrm{mmol} / 1$ at day 0 to $4.94 \pm 0.49$ by day 28 (Fig 1 ). Stored blood sodium was $145.15 \pm 2.84 \mathrm{mmol} / \mathrm{l}$ at day 0 , increased to $148.40 \pm 2.41 \mathrm{mmol} / 1$ by day 7 , and then at day 14 decreased to a value below $141 \mathrm{mmol} / \mathrm{l}$, which was the minimal value detected by the analyser (Fig 1). For each biochemical test, the increases or decreases between each time point were highly significant $(\mathrm{P}<0.0001)$.

The haematocrit increased significantly $(\mathrm{P}=0.0213)$ from $40.9 \pm 3.9$ per cent at day 0 to $59.2 \pm 12.8$ per cent by day 28 . On microscopic examination, the blood smears showed a moderate anisocytosis at day 0 ; by day 7 , moderate anisocytosis was still present, and many hypochromic RBCs and a few echinocytes (crenated, spiculed, spherical $\mathrm{RBCs}$ ) were seen. The number of echinocytes increased by day 14 , a few ghost cells (lysed RBCs) were visible and most RBCs were hypochromic. At day 21, all RBCS were hypochromic, the number of echinocytes was greatly increased and numerous ghost cells were visible; haemolysis was visible in the microhaematocrit capillary tube sample. By day 28, numerous echinocytes (>90 per cent) were seen (Fig 2); plasma in the microhaematocrit capillary tube was markedly haemolysed, and clots were microscopically visible on the blood smear.

\section{Discussion}

The results of the selected biochemical and haematological tests show the ongoing metabolism and deterioration of the RBCs in the stored blood. The unusually high glucose level of the stored blood at day $0(643 \pm 67 \mathrm{mg} / \mathrm{dl})$ is due to the presence of dextrose in the CPDA. It does not reflect the blood glucose levels of the donor ferrets. The manufacturer's material safety data sheet (MSDS) indicates

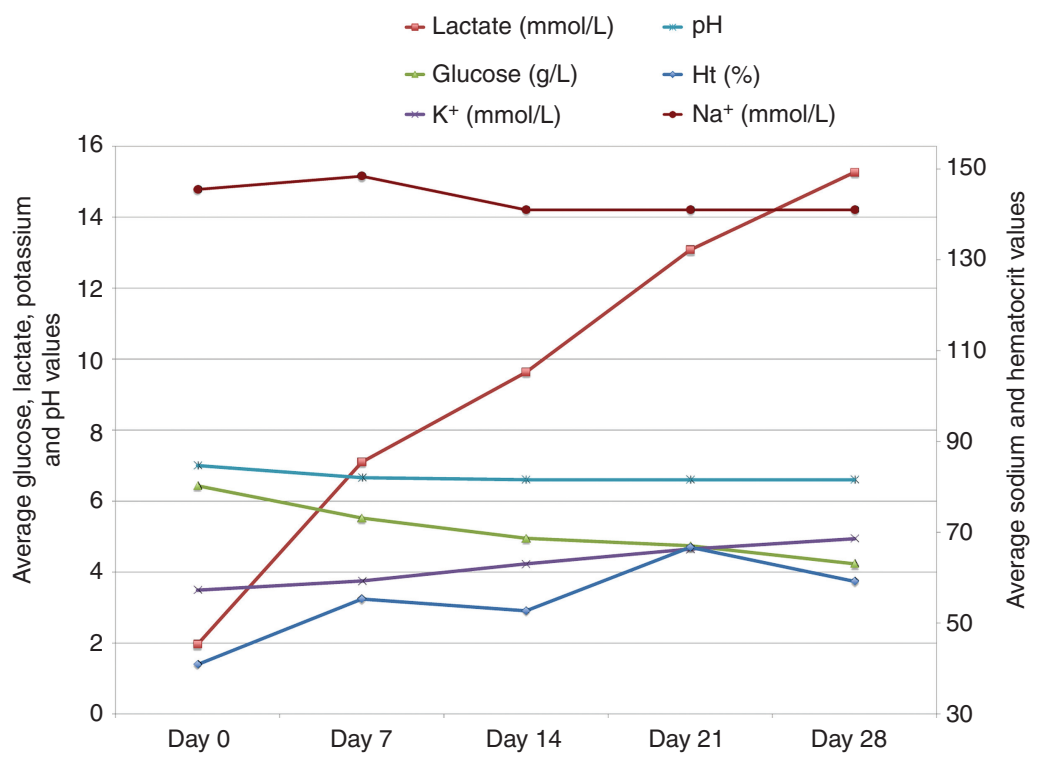

FIG 1: Average biochemical and haematocrit values of ferret blood stored in CPDA at $4^{\circ} \mathrm{C}$ over four weeks. Each time point represents the average value of 10 samples. The glucose values are shown as $\mathrm{g} / \mathrm{l}$ and not $\mathrm{mg} / \mathrm{dl}(1 \mathrm{~g} / \mathrm{l}=100 \mathrm{mg} / \mathrm{dl})$ in order to reflect the values on the left vertical axis 


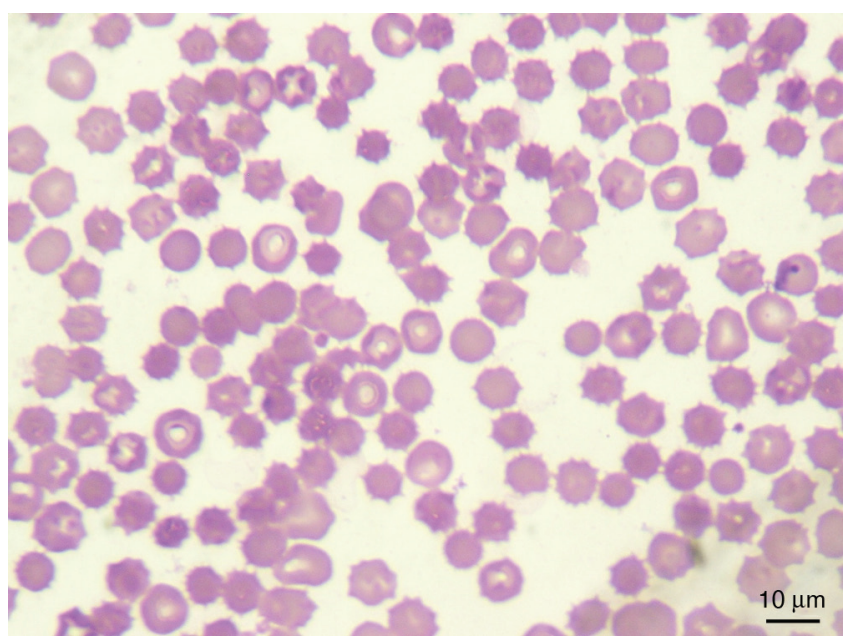

FIG 2: Photomicrograph of a blood smear of ferret blood stored in CPDA at $4^{\circ} \mathrm{C}$ after 28 days. All red blood cells show marked hypochromia and numerous echinocytes (crenated, spiculed red blood cells) are visible (May-Grünwald-Giemsa stain)

that CPDA solution is chemically stable under normal storage conditions. Therefore, the gradual reduction in glucose levels seen over time reflects consumption of glucose (and dextrose, the D-form of glucose) by the stored RBCs. Subsequent glycolysis within the stored RBCs produced lactate and hydrogen ions that decreased the $\mathrm{pH}$ of the stored blood. The heightened acidity of the stored blood then increased the permeability of the RBC membranes to potassium ions, resulting in a progressive rise in blood potassium.

The increase in the haematocrit of the stored blood samples over time can be explained by the morphologic modification of the RBCs. They are growing in volume because of their transformation into echinocytes. Erythrocytes have the shape of a biconcave disk. By contrast, echinocytes are spiculed spheres. The appearance of the blood smears reflects this change in $\mathrm{RBC}$ morphology during storage. The appearance of hypochromic RBCs and echinocytes probably reflects a deterioration of membrane permeability and deformability (BennettGuerrero and others 2007). These membrane alterations eventually lead to $\mathrm{RBC}$ rupture and haemolysis within the stored blood sample.

The biochemical and haematological results reflect a rapid deterioration of the $\mathrm{RBCs}$ during storage, more rapid than described for human or canine stored blood (Price and others 1988, BennettGuerrero and others 2007). By day 7, RBC biochemical and morphological measurements in stored ferret blood are significantly different from day 0 . Pronounced deterioration of the stored ferret RBCs is present by day 14 , as evidenced by numerous hypochromic RBCs, a moderate number of echinocytes and the appearance of ghost cells. By day 21, haemolysis is present and transfusion should not be performed.

Acid-base alterations, such as a decrease in the $\mathrm{pH}$, have been used to predict $\mathrm{RBC}$ viability of stored canine blood (Eisenbrandt and Smith 1973) although RBC concentrations of 2,3-diphosphoglycerate and adenosine-5-triphosphate are more sensitive. From day 0 to day 7 , the $\mathrm{pH}$ dropped from $6.99 \pm 0.70$ to $6.66 \pm 0.03$. Similar $\mathrm{pH}$ values do not occur until 21 days in stored human blood (Bennett-Guerrero and others 2007) and 14 days in stored canine blood (Price and others 1988), respectively.

Stored ferret blood for transfusion is problematic because RBCs, as they age in vitro, undergo numerous physiological changes that affect their shelf life. The metabolic and biochemical changes that occur in stored blood RBCs are collectively referred to as the 'storage lesions' (Doctor and Spinella 2012). Recently, concern has been expressed about potential adverse effects due to storage lesions in stored mammalian blood (primarily human, cat and dog). Some clinicians even suggest that older stored blood may cause increased morbidity and even mortality in transfused patients, despite the acceptable in-vivo survival of the stored blood RBCs (Pavenski and others 2012). Ideally, blood storage duration should be determined by in vivo post-transfusion viability measured as transfusion survival of radiolabeled or biotinylated RBCs at which 75 per cent $\mathrm{RBC}$ viability is maintained (Wardrop and others 1997). The limitation of this study is the lack of radiolabelled or biotinylated RBC survival data. However, when biochemical and haematological changes of stored ferret blood are compared with stored human or canine blood, such changes are more rapid in ferret blood. Consequently, our recommendations, while cautionary, are based on observations that show a low $\mathrm{pH}$, as well as the appearance of hypochromic RBCs and some echinocytes by day seven. We believe stored ferret blood in CPDA should not be used for transfusion in depressed patients after seven days. The further observation of haemolysis by day 21 prohibits any recommendation of using ferret blood stored for this period. In vitro studies measuring survival of labelled RBCs and in vivo studies using stored blood in sick ferrets will aid in evaluating the shelflife of stored ferret blood, based on our preliminary findings.

\section{Conclusion}

Ferret blood stored in PET vacuum blood tubes with CPDA should not be used for transfusion after seven days of storage at $4^{\circ} \mathrm{C}$ in patients. We recommend a maximum shelf-life of seven days for blood banking in ferrets, which is shorter than current recommendations for canine and feline stored blood.

\section{Acknowledgements}

The authors are grateful to Gwenaël Le Teuff from the Biostatistics and Epidemiology Service of the Gustave-Roussy Institute of Oncology for doing the statistical analysis of this study.

\section{References}

BENNETT-GUERRERO, E., VELDMAN, T. H., DOCTOR, A., TELEN, M. J., ORTEL, T. L., REID, T. S., MULHERIN, M. A., ZHU, H., BUCK, R. D., CALIFF, R. M. \& MCMAHON, T. J. (2007) Evolution of adverse changes in stored RBCs. Proceedings of the National Academy of Sciences of the United States of America 104, 17063-17068

DOCTOR, A. \& SPINELLA, P. (2012) Effect of processing and storage on red blood cell function in vivo. Seminars in Perinatology 36, 248-259

DUTTON, M. A. (1999) Transfusions in ferrets. Exotic Petersburg Practice 4, 33-34

EISENBRANDT, D. L. \& SMITH, J. E. (1973) Use of biochemical measures to estimate viability of RBCs in canine blood stored in acid citrate dextrose solution, with and without added ascorbic acid. Journal of the American Veterinary Medical Association 163, 984-987

FELDMAN, B. F. \& KRISTENSEN, A. T. (1995) Modern veterinary blood banking practices and their applications in companion animal practice. The Veterinary clinics of North America Small Animal Practice 25, 1231-1243

HILLYER, E. V. (1995) Blood collection and transfusion in ferrets. In Current Veterinary Therapy XII: Small Animal Practice. Ed J. D. Bonagura. Philadelphia: W.B. Saunders. pp 1341-1344

HOEFER, H. L. (1992) Transfusions in exotic species. Problems Veterinarians Medicine 4, 625-635

HOHENHAUS, A. E. (2004) Importance of blood groups and blood group antibodies in companion animals. Transfusion medicine reviews 18, 117-126

KAELBLE, M. K. (2000) Multi-systemic trauma in a ferret. Official Journal of the Veterinarians Emergency Critical Care 10, 13-18

LICHTENBERGER, M. (2004) Transfusion medicine in exotic pets. Clinical Techniques in Small Animal Practice 19, 88-95

MANNING, D. D. \& BELL, J. A. (1990) Lack of detectable blood groups in domestic ferrets: implications for transfusion. Journal of the American Veterinary Medical Association 197, 84-86

MORRISEY, J. K. (2010) Blood transfusions in exotic species. In Schalm's Veterinary Hematology. 6th edn. Eds D. J. Weiss \& K. J. WARDROP. Ames, IA: Wiley-Blackwell. pp 763-768

PAVENSKI, K, SAIDENBERG, E LAVOIE, M TOKESSY, $M$ \& BRANCH, D. R (2012) Red blood cell storage lesions and related transfusion issues: a Canadian Blood Services research and development symposium. Transfusion Medicine Reviews 26, 68-84 POLLOCK, C. (2007) Emergency medicine of the ferret. The veterinary clinics of North America Exotic Animal Practice 10, 463-500

PRICE, G. S., ARMSTRONG, P. J., MCLEOD, D. A., BABINEAU, C. A., METCALF, M. R. \& SELLETT, L. C. (1988) Evaluation of citrate-phosphate-dextrose-adenine as a storage medium for packed canine erythrocytes. Journal of Veterinary Internal Medicine 2, 126-132

RYLAND, L. M. (1982) Remission of estrus-associated anemia following ovariohysterectomy and multiple blood transfusions in a ferret. Journal of the American Veterinary Medical Association 181, 820-822

WARDROP, K. J., TUCKER, R. L. \& MUGNAI, K. (1997) Evaluation of canine red blood cells stored in a saline, adenine, and glucose solution for 35 days. Journal of Veterinary Internal Medicine 11, 5-8 


\title{
Veterinary Assessment of a blood preservation protocol Record for use in ferrets before transfusion
}

C. Pignon, T. M. Donnelly, C. Todeschini, J. Y. Deschamps and F. A. Roux

Veterinary Record 2014 174: 277 originally published online February 11, 2014

doi: $10.1136 / v r .102127$

Updated information and services can be found at:

http://veterinaryrecord.bmj.com/content/174/11/277

\begin{abstract}
These include:
References This article cites 15 articles, 1 of which you can access for free at: http://veterinaryrecord.bmj.com/content/174/11/277\#BIBL

Email alerting Receive free email alerts when new articles cite this article. Sign up in the service box at the top right corner of the online article.
\end{abstract}

\section{Notes}

To request permissions go to:

http://group.bmj.com/group/rights-licensing/permissions

To order reprints go to:

http://journals.bmj.com/cgi/reprintform

To subscribe to BMJ go to:

http://group.bmj.com/subscribe/ 